\title{
北西太平洋における台風発生50年確率波高の 長期的な変動の推定
}

\author{
畑田 佳男 1 ・白神 恭平2 \\ 1正会員 愛媛大学講師 大学院理工学研究科（干790-8577 愛媛県松山市文京町3） \\ E-mail: hatada.yoshio.mj@ehime-u.ac.jp \\ 2爱媛大学工学部 環境建設工学科（干790-8577 愛媛県松山市文京町3） \\ E-mail: shirakami.kyohei.09@ cee.ehime-u.ac.jp
}

\begin{abstract}
台風モデル法で海上風を推定した1934〜2013年の波浪推算結果から北西太平洋における50年確率波高 $H_{50}$ の経年変化を調査した。このため 80 年間の推算結果の中に開始時点を 10 年ずつずらした 30 年(あるいは 40 年)の波高資料を 6 組(5組)作成し，各組の $H_{50}$ の比較からつぎの結果を得た。 1)統計期間を 30 年とした $H_{50}$ は 多くの地点で明瞭な増減傾向を示さない， 2 期間を 40 年とした $H_{50}$ も同様な経年変化を示すが，その変動は 30 年の場合より小さい. 3$) H_{50}$ の算出に用いた年最大波高のトレンド示数 $I_{\mathrm{T}}$ 小九州西岸, 北海道南方沖で増 加傾向を示すものの, 有意な増減を表わ寸2を越える地点は数地点に限られる. 4)対象領域の $H_{50}$ は過去 80 年間においては顕著な増加減少傾向を示さない。
\end{abstract}

Key Words :50-year return wave height, trend, a parametric typhoon model, 80-year wave hindcast, Northwestern Pacific Ocean

\section{1. 緒言}

気候変動に伴う波浪の将来長期的な変動は海岸構造物 の設計において重要な要因の1つであり, 気象モデルか ら得られた海上風を入力条件とした波浪推算を基に推定 が行われている. しかしながら将来的な予測は平均波高 に関するものが多く，工学的に関心の高い波高の極值に ついての知見は限られている。.また予測は全球を対象に した場合が多いため，我が国周辺海域の様子が解りにく い. 森らは波浪推算モデル ${ }^{1)}$, 統計的モデル2かから極大 波高の将来的な変化を推定しており, 今世紀末にかけて 北西太平洋における極大波高の増大が予測されている.

本研究では我が国周辺の北西太平洋における過去の波 浪推算結果から，確率波高がどのような長期的変化傾向 をもつのか，現時点で変化の兆候が表れていないのかを 調査する. 対象海域で問題となる高波は台風により発生 すると考えられるので，簡便ではあるが長期間のデータ が取得された台風モデルにより海上風を推定した波浪推 算を行う。また 50 年確率波高 $H_{50}$ の経年変化を知るため 1934年～2013年(80年間)の波浪推算結果の中から統計期 間30年(あるいは40年)の波高推算資料を10年ずつずらし て6組(5組)作成し, 各組に対して求めた確率波高を比較 することから台風発生波高の再現確率值の長期的な変化 を調べる．同時に確率波高の算出に用いた年最大波高の
経年変化をそのトレンド示数から検討する.

\section{2. 確率波高の推定方法}

\section{(1) 波浪推算法}

対象海域は図-1に示寸我が国周辺の北西太平洋であり， 海上風および波浪とも格子間隔 $80 \mathrm{~km}(36 \times 35)$ の空間解像 度で計算を行った. 図-1中の赤い点は図-11で $H_{50}$ の経年 変化を検討する地点である. 波浪推算に用いた海上風は

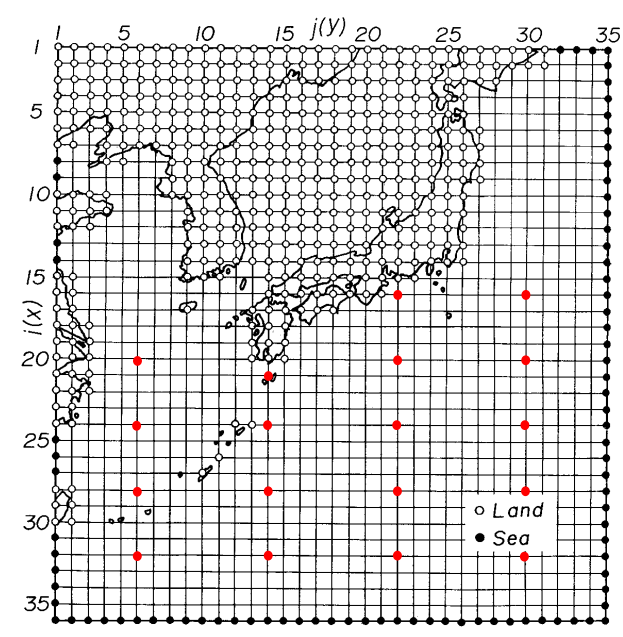

図-1 波浪推算の計算格子 


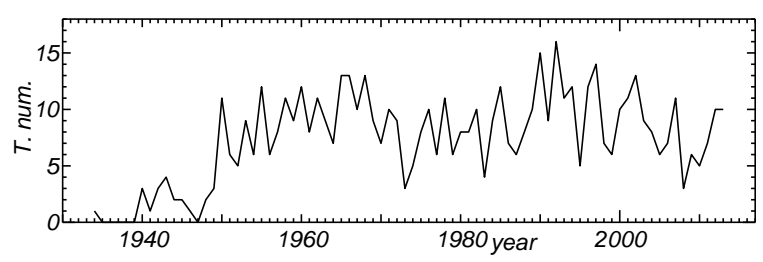

図-2 対象台風個数の経年変化

表-1 推算精度を検討した台風

\begin{tabular}{r|c||r|r||r|r}
\hline No. & T.No. & No. & T.No. & No. & T.No. \\
\hline 1 & 1007 & 6 & 1112 & 11 & 1216 \\
\hline 2 & 1014 & 7 & 1115 & 12 & 1217 \\
\hline 3 & 1102 & 8 & 1204 & 13 & 1318 \\
\hline 4 & 1106 & 9 & 1210 & 14 & 1324 \\
\hline 5 & 1109 & 10 & 1215 & 15 & 1326 \\
\hline
\end{tabular}

気圧分布にMyers式を仮定した台風モデル法により1時間 間隔で推定する。波浪推算は山口らの波浪推算モデル3 で水深を無限大とした深海波浪推算モデルによる．実際 の推算では計算時間間隔1時間で方向スペクトルを算出 し，これから有義波高 $H_{\mathrm{s}}$ を求める. 方向スペクトルの成 分は $0.047 \sim 1 \mathrm{~Hz}$ の 20 個の周波数, $0 \sim 360^{\circ}$ を $20^{\circ}$ で分割 した19万向である. 以下の波高は有義波高 $H_{\mathrm{s}}$ あ゙る.

\section{(2) 対象台風}

確率波高の推定に用いた台風は1934年～2013年の80年 間の590個である。これらのうち1951年以降については 図-1の領域内で中心気圧が980hPa以下になった台風を対 象とするが，これ以前については発達した巨大台風に限 られる. 図-2は対象台風個数の経年変化であり，1948年 以降には毎年台風データがあるが1949年，1973年，1983 年，1995年，2008年は5個未満と少なく，1947年以前に は台風データの無い年もある. 毎年台風データのある 1948年 2013年における対象台風の年平均個数は8.7個程 度である.

\section{(3) 極值解析法}

極值統計解析には, Gumbel分布, Weibull分布（形状母 数 $\mathrm{k}=0.5 \sim 10$ の 27 種類）, FT- II 型分布（形状母数 $\mathrm{k}=2.5 \sim$ 40 の20種類）の計48種類を候補分布とし，標本資料に対 する非超過確率值の割当てを合田のプロッティング公式 4), 尺度母数と位置母数の推定を最小 2 乗法, 最適分布 の選択を最大相関係数基準, 再現確率值の標準偏差の推 定をjackknife法によるYamaguchi・Hatada ${ }^{5)}$ のテデを用い る.また1947年以前の対象台風ケース数が少ないことお よび同期間の台風は巨大台風を中心に選択されているこ とを考慮して極值資料には資料採択率 $v$ を上位 $1 / 3$ に設 定した年最大波高資料を用いた。

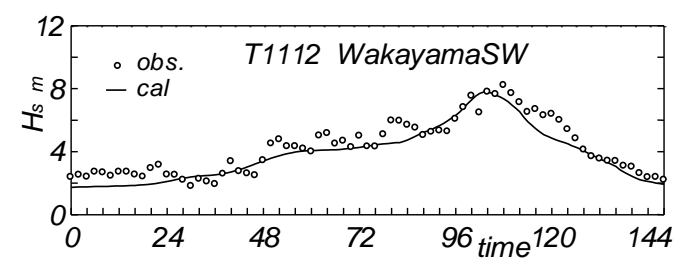

図-3 有義波高の経時変化の比較例

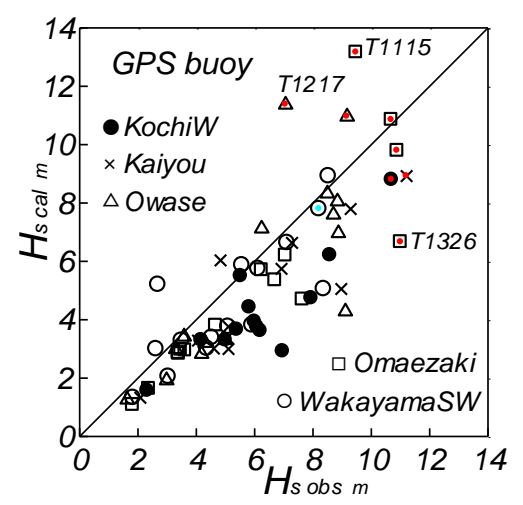

図-4 台風期間最大波高の相関

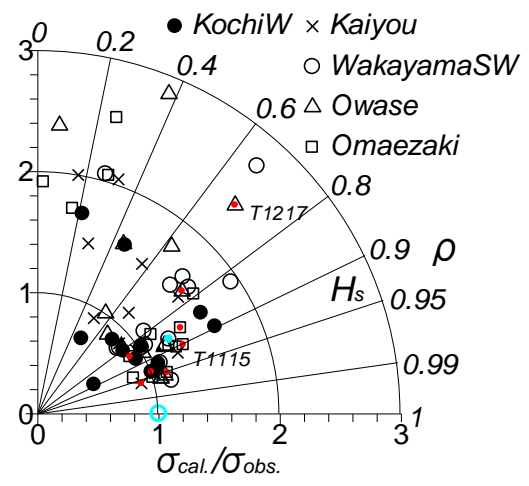

図-5 Hs の推算值と観測值の Taylor 図

\section{3. 推算精度の検討}

波浪推算精度の検討は，格子間隔 $80 \mathrm{~km}$ と荒い計算で あるため，日本沿岸で台風の影響を受ける沖合の波浪観 測点で行う。このため高知県西部沖〜御前崎沖に至る NOWPHASのGPSブイ 5地点で2010年〜2013年の15台風時 のHsの推算結果を観測結果と比較した。表-1は比較対象 台風の一覧であり，比較ケース数を確保するために東シ ナ海を北上した台風1215号のように離れた経路をもつ台 風を含んでいる. 図-3はHs の経時変化の比較例である. 推算結果は発達期から減衰期に至る観測結果の経時変化 に対応している.このケースは以下の図-4および図-5中 に青色で示されている. 図-4は各台風時の最大有義波高 を推算結果と観測結果について比較した相関困である. 図中，観測值あるいは推算值が $10 \mathrm{~m}$ 越える場合に赤く 


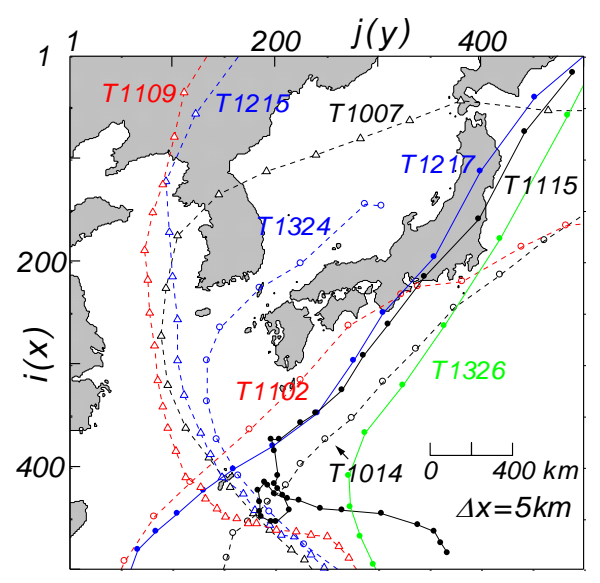

図-6 推算精度の低い台風の経路

着色するととともに相関の低いケースに台風番号を付記 してある. 台風1326号は本州南岸を台風1115号と1217号 は観測地点の近傍を北東に進んだ台風であり，陸から風 が吹送した場合や時空間変化の激しい場合に推算精度が 低下している. 全体として推算結果は観測結果より小さ い傾向を有するものの高波高時には完全相関直線の上下 に作図され，観測結果に対して特定の偏りをもたないと いえる. 図-5は台風毎に推算結果と観測結果の相関係数 $\rho$ とそれぞれの標準偏差の比 $\sigma_{\mathrm{cal}} / \sigma_{\mathrm{dok}}$ を1点で描画した Taylor 図のである. Taylor図は半径方向に標準偏差比 $\sigma_{\mathrm{cal}} / \sigma_{\mathrm{obs}}$, 動径方向に相関係数 $\rho$ をったた図であり, 青丸 で表示した目標值（1，0）に近い程，推算結果と観測結 果の対応が良いと判定される．また図-4で着色した高波 高ケースは図-5でも赤く着色されている，高波高ケース は目標值（1，0）に近い位置にあるが，台風1217号時の 尾熟は目標值から遠い点に描画されている。図-6は Taylor 図上で推算精度の低い $\left(\sigma_{\mathrm{cal}} / \sigma_{\mathrm{obs}}>2\right)$ と判断され た台風の経路図である，比較地点から遠い経路を通った 台風あるいは複数の台風や低気圧が存在した場合に目標 值（1，0）から離れた位置に描画される. このように推 算結果と観測結果の対応の低下寸る場合もあるが，図-3 のようなケースでは相関図およびTaylor図とも推算精度 が良好な位置に作図されること，推算結果は観測結果よ りやや小さい傾向を有するものの，高波高時には観測結 果に対して特定の偏りをもたないことなどから， $H_{50}$ の 長期変動の推定に必要な精度をもつと判断した.

\section{4. 確率波高の推定結果}

\section{(1) 確率波高 $H_{50}$ の経年変化}

まず1934年から2013年において開始時点を10年ずつ ずらした30年間の年最大波高資料を 6 期間作成し，各期 間の極值解析から求めた $H_{50}$ の平面分布からその経年変 化の概略を把握する. 30年間における年最大波高資料
を重複させながら6期間作成し，各期間の $H_{50}$ から経年変 化を調査する方法に理論的な根拠は無いけれども，確率 波高の推定には少なくとも30年程度必要であること，で きるだけ多くの期間に対する $H_{50}$ で経年変化を表示する という観点からこのような方法をとった。 図-7は各30年 間の対象台風経路を例示した図であり，上側に期間と台 風個数（括弧内）を表す．1964年以降の経路図は台風個 数が275個前後をとって1954年〜の期間と大差なく，分 布パターンも同様であるので，1964年以降の各30年間に ついては1984年〜の期間のみ示されている. 最初の 2 期 間は残りの期間に比べて台風個数が少なく，経路図の分 布密度も低い，図-8は1934年および1944年から始まる30 年間より求めた 2 期間の $H_{50}$ を，図-9は残りの4期間の $H_{50}$ を左側ほじ過去になるように配置した平面分布図である。 $H_{50}$ は図-8および図-9の1954年〜の期間において領域の東 端付近で17mを越えるが，これらの期間と南端境界付近 の一部を除けば本州南方で14〜16m程度の值をとる.

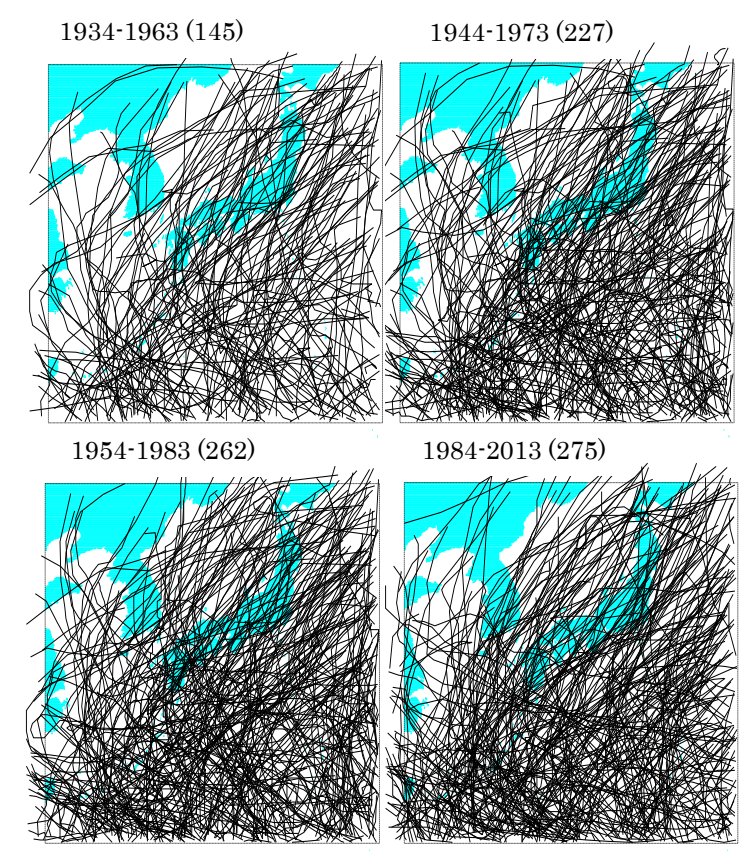

図-7 各 30年間の台風経路
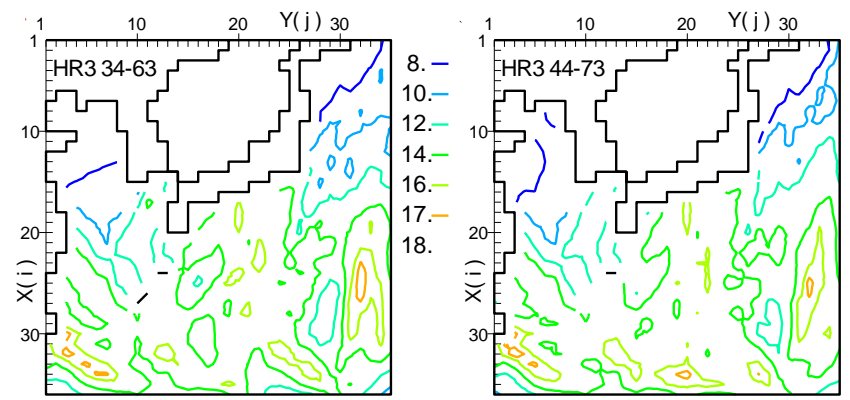

図-8 各 30 年間の $H_{50}$ 

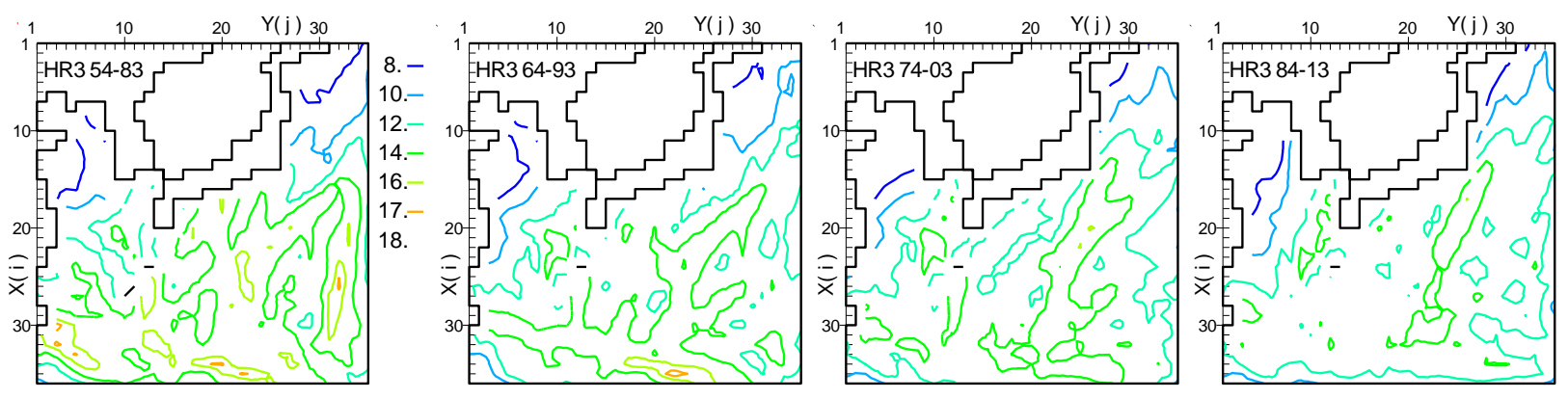

図-9 1954 年から開始年を 10 年ずつずらした各 30 年間の $H_{50}$
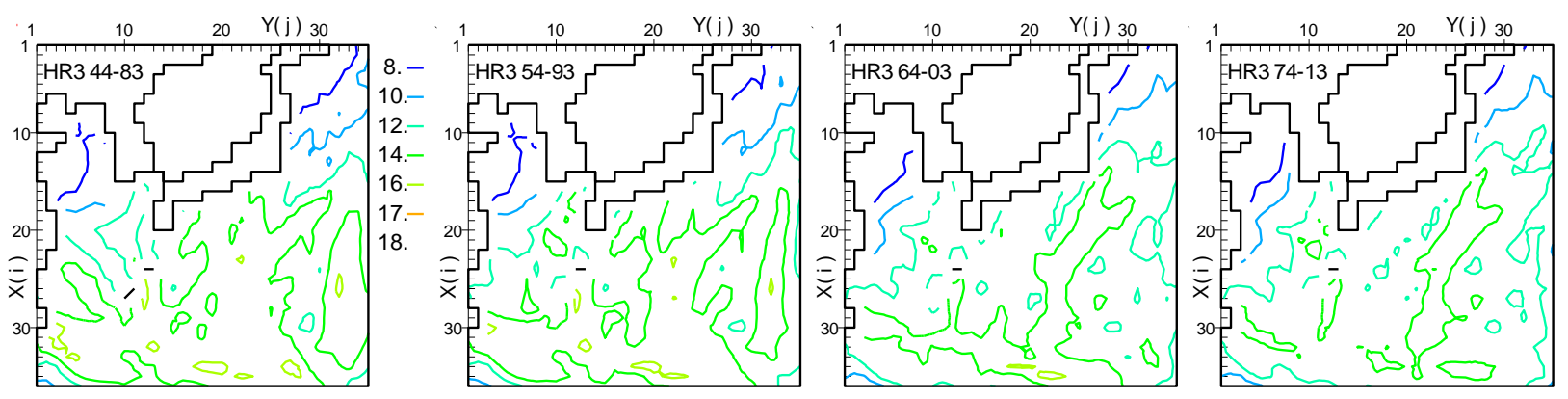

図-10 1944 年から開始年を 10 年ずつずらした各 40 年間の $H_{50}$

1964年以降に設定した後半の3期間では年代につれて若 干小さくなるものの類似した平面分布を示す. 図-10は 統計期間を40年とした $H_{50}$ を図-9 と同様に表している. 1934年〜の期間は1944年〜の平面分布に似ているため省 かれている. また期間40年に対応する台風経路図も掲載 されていないが，各期間の台風個数が30年の場合より 80 個ほど増えて経路が稠密になるため年代による変化が識 別し難い図となる。図-10によれば40年間に対して求め
た $H_{50}$ も本州南方で14〜 $16 \mathrm{~m}$ 程度をとり 30 年間に対して求 めた $H_{50}$ と同様な平面分布を示すが，期間による変化は 30年間の場合より小さい. 図-8～図-10より $H_{50}$ は期間30 年の場合に台風数の少ない1934年〜1954年で他期間より 大きい結果，弱い減少傾向を有するように見えるが，期 間を40年とすれば台風数の変化による影響が弱まって緩 やかな経年変化になり, 領域全体で顕著な経年的変化を 示さないように見える.
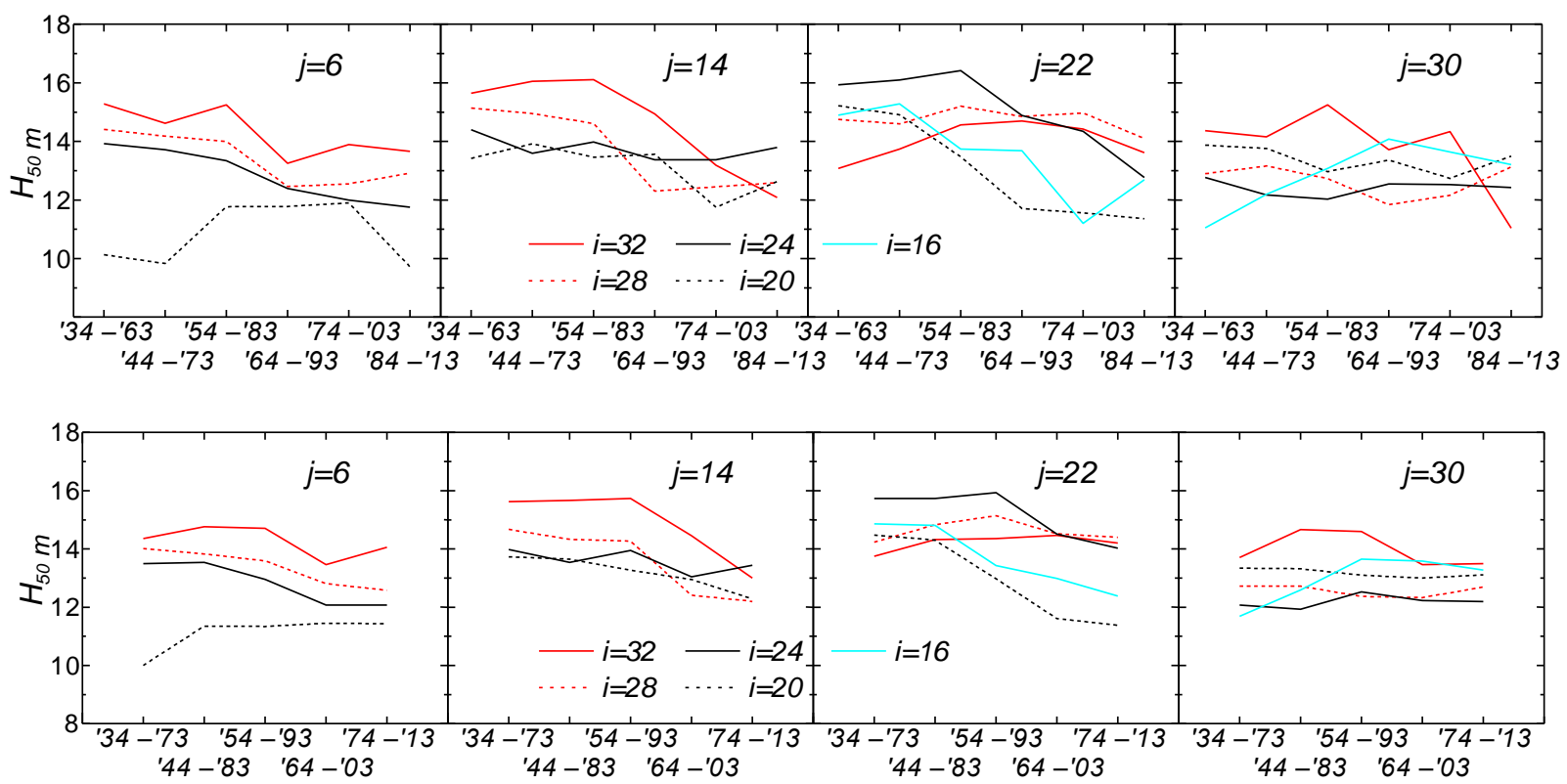

図-11 30年間 (上段) および40年間（下段）について求めた $H_{50}$ の経年変化 
図-11は図-1に赤色で示した18地点における $H_{50}$ の経年 変化を示した図であり，上段が30年間，下段が40年間か ら作成された $H_{50}$ である. 各段は右側が東側になるよう に配置した4枚の小図からなり，各小図内では北に向か って赤, 黒, 青 $(\mathrm{j}=22$ と $\mathrm{j}=30$ の久青色の $\mathrm{i}=20$ 地点が追加 されている），同色では北側の地点が点線で表示されて いる．作図地点の間隔は南北方向 $320 \mathrm{~km}$, 東西方向 $640 \mathrm{~km}$ で, 全18地点で大略南北1200km, 東西1800kmほど の領域（先島諸島から小笠原諸島付近の本州南岸）にお ける $H_{50}$ の経年変化を例示している. なおj $=14 の$ 地点では $\mathrm{i}=20 か ゙$ 陸地のため 1 格子南側の地点を用いる. $H_{50}$ はj $=6$ と $\mathrm{j}=14$ で南側ほど大きい傾向を示すが，残りの地点では系 統的な空間変化を示さず， $11 \mathrm{~m} \sim 16 \mathrm{~m}$ の範囲をとる. $H_{50}$ の経年変化は弱い減少傾向にある地点が多いものの地点 毎に異なる变化を示し, 全地点に共通した強い増加ある いは減少傾向をもたないようである。また $H_{50}$ の経年的 な変動は40年間から求めた結果が30年間から求めた場合 より小さいけれども両者の変化傾向に大きな違いはない. したがって本州南方沖において $H_{50}$ は顕著な経年変化を 示さないといえる.

\section{(2) 年最大波高の経年変化}

ここでは確率波高の算出に用いた推算年最大波高の経 年変化について述べる，図-12は80年間のうち台風デー タの有る年が連続した1948年から2013年(66年間)の年最 大波高の時系列資料から求めたトレンド示数 $I_{\mathrm{T}}^{7}$ の平面 分布である. I

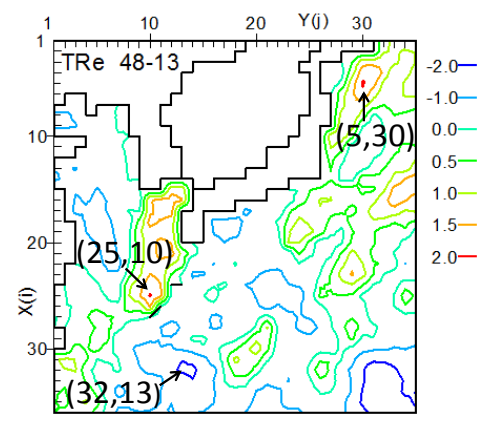

図-12 年最大 $H_{\mathrm{s}}$ のトレンド示数

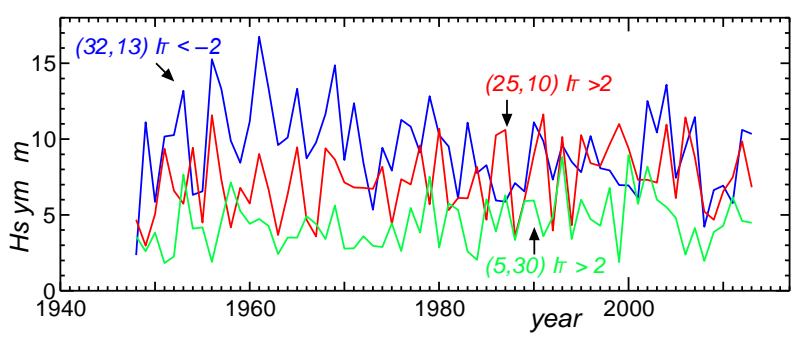

図-13 $\left|T_{T}\right|>2$ となる地点における年最大波高の経年変化
以降にある值以上の值が現れる回数に着目してトレンド を判断する示数である. I $I_{\mathrm{T}}$ 正であれば増加傾向, 負で あれば減少傾向を示し，その絶対值が2を越えれば有意 な変化とする指標である. 対象領域では九州西岸や北海 道南方沖で増加傾向が，南方沖で減少傾向が表れている. $I_{\mathrm{T}}$ の絶対值が2を越える領域は図中に格子番号を示した 地点に限られ，その值は-2.14 (32, 13)，2.03(25, 10)，2.05(5, 30)である. したがって年最大波高は対象領域において 顕著な変化傾向を示さないと考えられる. 図-13は図-12 において $I_{\mathrm{T}}$ の小さ地点 $(32,13)$, と大きい地点 $(25,10),(5$, 30)における年最大波高の経年変化図である. 九州南方 沖の $(32,13)$ では1950年〜1960年に高波高が出現した後, 次第に減少している. 沖縄北方の $(25,10)$ では1960年代に 穏やかで1990年頃に高波が続く経年変化を示すが，強い 増加傾向を持つ印象はない. 北海道南方沖の $(5,30)$ では 1980年から2000年にかけて高波高が連続するため弱い増 加傾向にあるように見える. これらから $I_{\mathrm{T}}>2$ となる地点 においても2.05程度であれば年最大波高は強い増加傾向 を示さないといえる. 図-14は図-13に示した3地点につ いて40年間（左側）および30年間（右側）から求めた $H_{50}$ とその標準偏差の範囲を表している. $H_{50}$ は $(32,13)$ で 減少傾向, $(25,10)$ と $(5,30)$ で弱い増加傾向を示し, 年最 大波高の $I_{\mathrm{T}}$ の小に対応した増減を示寸. 年最大波高の $I_{\mathrm{T}}$ において経年変化が有意と判定されても，その值が 2.1 を越えなければ $H_{50}$ の変化傾向は明瞭でない，図-15は $\left|I_{\mathrm{T}}\right|>2$ となる地点と残りの地点の相関係数を年最大波高の 経年值について示した図である. 左側は減少傾向のあっ

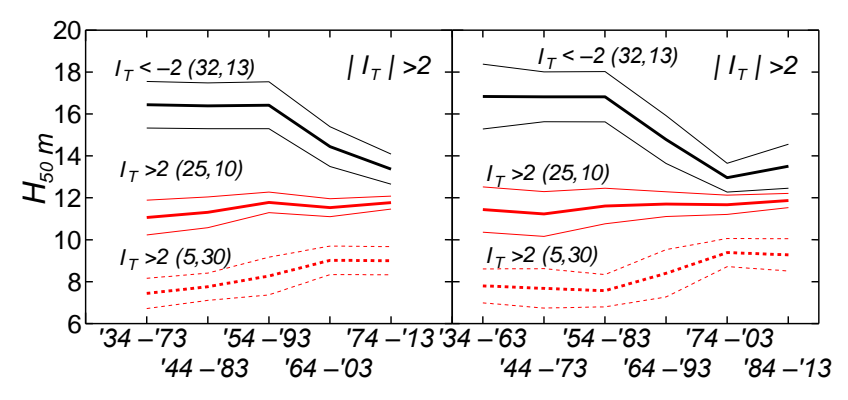

図-14 $\left|I_{\mathrm{T}}\right|>2$ となる地点における $H_{50}$ の経年変化
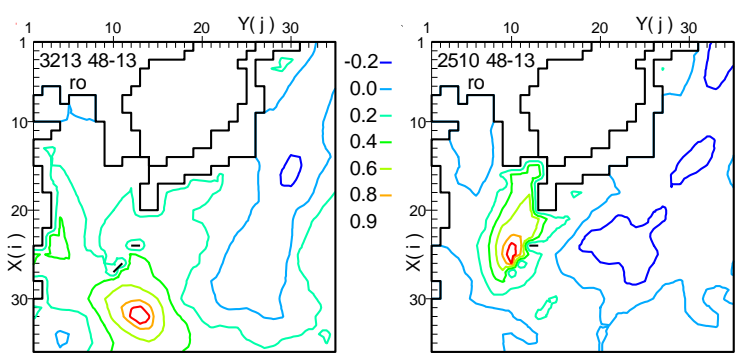

図-15 $\left|I_{T}\right|>2$ となる地点と他地点の年最大波高の相関 
た(32, 13), 右側は増加傾向にあった $(25,10)$ 地点の相関係 数を表している. 等值線は $(32,13)$ で円形に近く, $(25,10)$ では台風経路の卓越方向に近い北北東に伸びる楕円形を

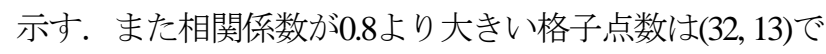
8個，(25,10)で6個であることから，年最大波高の経年変 化の似た地点は周辺に限られている. したがって $I_{\mathrm{T}}$ の值 から有意な変化傾向があると判定された地点があったと しても似た経年変化を示す範囲は狭いと考えられる.

\section{5. 結語}

以上，四国沖から御前崎沖のGPSブイで台風時におけ る推算波高と観測波高の比較から推算精度を確かめたの ち，北西太平洋における1934年 2013年の台風時波浪推 算から得た50年確率波高について経年変化を検討した。 得られた結果は以下のようである.

1) 1934年 2013年に10年ずつずらして作成した6期間各30 年間に対して推定した50年確率波高は弱い減少傾向を有 する場合もあるが，北西太平洋全体で見れば顕著な増減 を示さない.

2) 5期間40年間の50年確率波高も30年間を対象とした場 合と似た経年変化を示すが，その変動は30年間の場合よ り小さい.

3) 連続した年最大波高の得られる1948年 2013年に対し て推定したトレンド指数の平面分布によれば，九州西岸， 北海道南方沖に弱い増加傾向がみられるものの，2を越 える地点は数地点に限られる.

以上より，北西太平洋における台風に起因する年最大 波高とこれから求まる50年確率波高は，対象とした過去
80年間に限れば系統的な増加・減少傾向を示さないとい える.

謝辞 : 推算精度の検証に使用したGPS波浪計のデータは, 国土交通省港湾局によって観測され，港湾空港技術研究 所で処理されたものであり，ここに記して謝意を表しま 于.

\section{参考文献}

1) 森 信人, 志村智也, 安田誠宏, 間瀬 肇: 地球温暖 化に伴う極大波高の将来変化予測, 土木学会論文集 B2(海岸工学), Vol. 66, No.1, pp. 1231-1235, 2010.

2) 森 信人, 岸本理紗子, 志村智也, 安田誠宏, 閒瀬 肇: 全球の統計的波高推定手法の開発と将来変化予測 への応用, 土木学会論文集 B2(海岸工学), Vol. 71, No.2, pp.1_1501-1_1506, 2015.

3) 山口正隆, 畑田佳男, 細野浩司, 日野幹雄 : エネル ギー平衡方程式に基づく浅海波浪の数值予知モデル について, 第 31 回海岸工学講演会論文集, pp.123〜 127, 1984.

4) 合田良実：耐波工学, 鹿島出版会, 430p., 2008.

5) Yamaguchi, M. and Y. Hatada : An extremal analysis system and its application to the estimation of extremes of meteorological and oceanographic elements around the coasts of Japan, Proc. WAVES97, Vol. 2, pp. 932-946, 1997.

6) Taylor, K. : Summarizing multiple aspects of model performance in a single diagram, J. Geophys. Res., Vol.106,No.D7, pp.7183-7192, 2001.

7) 鈴木栄一: 気象統計学(第 5 版), 地人書館, $314 p$., 1975.

(2016.3.16 受付)

\title{
ESTIMATION OF LONG TERM VARIABILITY OF TYPHOON GENERATED 50- YEAR RETURN WAVE HEIGHT IN THE NORTHWESTERN PACIFIC OCEAN
}

\author{
Yoshio HATADA and Kyohei SHIRAKAMI
}

Variability in long periods of typhoon generated 50-year return wave height $H_{50}$ in the Northwestern Pacific Ocean was estimated by wave hindcasts. The wave hindcasts are conducted from a period of 80 years using a parametric typhoon wind and wave prediction model in deep water. To estimate the variability of return wave height, $H_{50}$ was estimated for each of six 30-year sets of annual maximum wave height data obtained between 1934 and 2013, with a 10-year forward shift for the beginning of each data set. Five sets of annual maximum wave height data from periods of 40 years were also used to compare with the $H_{50}$ for the 30-year period data. Trend indices of annual maximum wave heights are estimated over a 65-year period when the annual values are obtained continuously. Main results are as follows: 1) $H_{50}$ obtained from the 30-year periods shows no remarkable yearly increase or decrease over the large area. $H_{50}$ obtained from the 40-year periods shows the same trend with less yearly change than that of the 30-year periods. 2) Trend indices of annual maximum wave heights show that no significant increase or decrease is detected in the area. 3) As far as the last 80 years is concerned, $H_{50}$ shows no remarkable increase of decrease in the Northwestern Pacific Ocean. 